\title{
Correction to: Evidence of climate-driven changes on atmospheric, hydrological, and oceanographic variables along the Chilean coastal zone
}

\author{
Patricio Winckler Grez ${ }^{1,2,3}$ (D) Catalina Aguirre ${ }^{1,3,4}$ - Laura Farías ${ }^{4,5}$. \\ Manuel Contreras-López ${ }^{6}$. Ítalo Masotti ${ }^{3,4,7}$
}

Published online: 28 December 2020

(C) Springer Nature B.V. 2020

\section{Correction to: Climatic Change (2020) 163:633-652 https://doi.org/10.1007/s10584-020-02805-3}

The article Evidence of climate-driven changes on atmospheric, hydrological, and oceanographic variables along the Chilean coastal zone, written by Patricio Winckler Grez, Catalina Aguirre, Laura Farías, Manuel Contreras-López \& Ítalo Masotti, was originally published online on 6 November 2020 with Open Access under a Creative Commons Attribution (CC BY) licence 4.0. After publication in volume 163, issue 2, page 633-652 the author(s) decided to cancel the Open Access. Therefore, the copyright of the article has been changed on 16 December to (C) Springer Nature B.V. 2020with all rights reserved.

Publisher's note Springer Nature remains neutral with regard to jurisdictional claims in published maps and institutional affiliations.

The online version of the original article can be found at https://doi.org/10.1007/s10584-020-02805-3

Patricio Winckler Grez patricio.winckler@uv.cl

1 Escuela de Ingeniería Civil Oceánica, Universidad de Valparaíso, Valparaíso, Chile

2 Centro de Investigación y Gestión de Desastres Naturales (CIGIDEN-PUC), Santiago, Chile

3 Centro de Observación Marino para estudios de Riesgos del Ambiente Costero (COSTAR-UV), Valparaíso, Chile

4 Centro de Ciencia del Clima y la Resiliencia (CR2), Santiago, Chile

5 Departamento de Oceanografía, Universidad de Concepción, Concepción, Chile

6 Facultad de Ingeniería y Centro de Estudios Avanzados, Universidad de Playa Ancha, Valparaíso, Chile

7 Facultad de Ciencias del Mar y de Recursos Naturales, Universidad de Valparaíso, Valparaíso, Chile 